\title{
Students demographic variables as determinants of utilisation of information resources among undergraduates of universities in South-South Nigeria
}

\author{
Ama-Abasi R. Daniel ${ }^{1}$, Undie M. Agba ${ }^{2 *}$ \\ ${ }^{1}$ Lecturer II, ${ }^{2}$ Assistant Lecturer, Dept. of Library and Information Science University Calabar, Cross River State, Nigeria
}

*Corresponding Author: Ama-Abasi R. Daniel

Email: undiemoses@unical.edu.ng

\begin{abstract}
This study was undertaken to find out the influence of students' demographic variables on utilization of information resources among undergraduates in universities in South-South Nigeria. The objectives were to determine whether gender, age and academic level of students influence utilization of information resources. To guide the study three hypotheses were formulated. Related literature and empirical studies were also reviewed. Survey research design was also adopted to guide the study. The stratified random sampling technique was adopted in this study to get the universities and accidental sampling technique to get data from the students. A total of one thousand students were used in this study. A questionnaire was used to collect data from the students. One-way analysis of variance and independent t-test were used for data analyses. The result showed that academic level of students influences utilization of information resources, gender and age of students did not significantly influence utilization of library information resources. It was concluded that students should have positive outlook in all their life's endeavours including their academic pursuits so that they can maximally utilize the quantum of information resources available in the Libraries in Nigerian Universities for improved academic performance and competitive global academic pursuit.
\end{abstract}

Keywords: ICT Innovation, Electronic Resources, User Education, Academic Libraries, Knowledge generation, Demographic Characteristics.

\section{Introduction}

People need information for making relevant decisions. Hence, they may acquire this information through the means of researching, which entails the process of finding ideas, facts and new information by a scientific and systematic study. The library then serves as an important channel where information is acquired, processed and disseminated through the provision of appropriate information resources in its various formats including print and non-print formats. Library resources are therefore critical to a student's academic activity.

Universities are to generate new knowledge and also encourage the adoption of the ICT innovation. The library as an information centre, is saddled with the responsibility of generating information resources to address users' needs and demands, irrespective of classes or races in the society. This effort is to attract and encourage their clients especially the students, to visit and make use of the library. However, studies show that students attitude towards the use of library resources vary.

Observations have shown that most students do not make use of available information resources at their disposal, despite the modern innovations by providing both traditional and electronic libraries and serene environment. Utilisation of library information resources and services has been a concern from the time libraries changed from being cultural monuments to knowledge acquisition and information communication centres.

In view of these developments, Librarians conceived the idea of educating the library users in finding and locating information they need on the day to day activities. ${ }^{2}$

Demographic characteristics of students also have a significant impact on the use of institutional library resources. Momudu (2015) submitted that female students in Ambrose
Ali University used the library more than their male counterparts. Demographic data such as age,

gender, level of study often yield important clues as to what factors contribute to undergraduates' use of information resources. Age is a variable that correlates with or conform with computers and use of electronic resources. Younger generations have been brought up with computers. Older students may not have had such exposure and as such there is increased computer anxiety among this group. Gender gap relating to computer use seems to be shrinking as male seems to enjoy browsing while females tend to use it for work related purposes.

This study is thus aimed at investigating the extent to which demographic variables of students influence utilization of information resources among undergraduates of Universities in South-South Nigeria.

\section{Statement of the problem}

There has been growing concern about students' use of the library in higher institutions of learning in Nigeria. This concern arises due to the importance of the library in the successful completion of their studies. Information is vital in every day functioning. This is because as the saying goes an individual who is not informed is deformed and this can go a long way in influencing the activities of the individual. Therefore, students who deal directly with pieces of information on daily basis are expected to utilize all forms of information relevant to their studies either in print or nonprint form. ${ }^{4,5}$

Unfortunately, observations have shown that most students do not make use of available information resources at their disposal. This researcher has observed that some well equipped libraries are underutilised. Demographic data such as age, gender and level of study often yield important clues 
as to what factors contribute to undergraduates' use of library resources as this will provide elicit suggestions for improved use of the library. It was on this basis that this study was carried out to examine students' demographic variables (gender, age and level of study) as determinant of utilization of information resources among undergraduates.

\section{Purpose of the study}

The purpose of this study was to investigate the influence of student's variables on utilization of information resources among undergraduates in universities in South-South, Nigeria. Specifically, the researcher sought to find out whether:

1. Gender significant influences utilization of information resources among undergraduates.

2. Age significant influences utilization of information resources among undergraduates.

3. Academic level of students significant influences utilization of information resources among undergraduates

\section{Research questions}

The following research questions were posed to guide this study.

1. Does gender significant influence utilization of information resources among undergraduates?

2. To what extent does age significant influence utilization of information resources among undergraduates? ${ }^{6}$

3. Does academic level of students significantly influence utilization of information resources?

\section{Statement of hypotheses}

The hypotheses were stated in null form as follows:

1. Gender does not significantly influence utilization of information resources among undergraduates

2. Students' age does not significantly influence utilization of information resources among undergraduates

3. There is no significant influence of academic level utilization of information resources among undergraduates.

\section{Significance of the study}

The result of this study may be beneficial to the government (policy makers, individuals), universities, library and library users. It may enable the policy makers to formulate appropriate policies that may enhance the type of information resources to be donated or bought for the library. It may also help government to be aware of current trends in the library sector and work towards achieving its goal and maintaining the standards of the library.

It is equally expected that the result of this study may help the university to provide adequate fund for sustaining library services. It may also increase value, that is, quantity and quality of information resources available to staff, students and individual users, thereby supporting the mission of each institution. This as well may help library users and staff to have knowledge of what is available in academic libraries and what is expected in the libraries. And create more opportunities for library users through user education and other skills development opportunities. ${ }^{8}$

\section{Literature Review}

Many scholars have discussed the issue of gender difference among students towards the use of library resources. Hayelom (2014) explore on the determinants of information resources and services used among students and instructors on gender. The descriptive statistics result indicated that male respondents were $56.1 \%$ whereas female respondents were $43.9 \%$. Chi- square test was used and it was observed that $84.3 \%$ of male patronized the library while only $35.4 \%$ of female utilized the library. The result indicates high usage by male students. In the same approach, Manda and Mulkangara (2007) report that gender is associated with the use of electronic information resources, and that male postgraduate students were more likely to use e-resources than female students. They further reported that even when there was controlled for attitude towards the use of e-resources or training in the use of e-resources, the relationship between gender and e-resources was maintained. In a similar view, Amkpa (2007) revealed that male and female students differ significantly in attitudes towards computer applications, which later affected their job opportunities after graduation. Losh (2003) and Fallows (2005) studies reveal that gender differences exist in the use of Internet between men and women. The longitudinal study of Pew Internet and American life project reported by Fallows (2005) has shown that women appreciate especially the communicative features of the Internet, while men are more likely to use online transactions, get information, play games and use entertainment.

Commenting on the age and utilization of electronic resources, Tenopir (2003) posit on use and users of electronic library resources: An overview and analysis of recent research studies using the University of Tennessee, Knoxville as a case study posits that there is some evidence that younger users are more enthusiastic adopters of digital resources than are older users. Younger users rely on electronic resources more heavily and rate themselves more expert in using them than do older users. Similarly, Lucky (2016) maintain that there is significant age differences in the utilization of information resources that Postgraduate students of library and information science are quite aware and highly use electronic information resources. Quadri (2013) posit that Students' demographic factors should not be a barrier to e-resources use and as a result, students of all ages should endeavour to acquire knowledge required to enable them make effective use of online library resources anytime and anywhere. Also that both young and old student should be encouraged and sensitized on the benefits available in the use of library online resources. Clabo (2002) in his findings showed that high school students who used the library as a child reported higher use rates than the students who did not use the library as a child. They found that most students visited the library at an early age with their mothers, although not on a regular basis. Waldman (2002) posited that age is one variable that correlates with comfort with computers and 
use of electronic resources. Okiki (2011) also posited that younger generations have been brought up with computers, older and returning students may not have had as much exposure to computers, resulting in increased computer anxiety. ${ }^{9}$

On the academic level and utilization of information resources, Andalee and Simmon (2001) conducted a study entitled "Usage of academic libraries: the role of service quality, resources and user characteristics." Using multistage sampling and the probit regression technique, it was revealed that the use of academic library is influenced mostly by a user's perceived familiarity with the library and its resources. They also reveal that those who are more familiar with the library are more likely to use academic libraries. While Teoh and Tan (2011) examined the determinants of library use amongst university students. Logistic regression analysis was applied. They found that users who believed that the library provides a useful avenue for them to achieve their academic goals and frequent online users are more likely to utilize the library than their cohorts. Nnadi (2016). Notted that: undergraduate students' use of electronic information resources enhances their access to a wider range of information, most of them prefer to use internet for their academic work, and they prefer to use phones and laptops as their sources of electronic information resources. They are motivated to use electronic resources because they provide quick access to information. Gakibayo and Ikoja-Odongo (2013. In a related study found that utilization of e-resources is not only affected by lack of computer skills and information literacy skills but also lack of enough computers, students attitude to library resources and slow internet connectivity affected utilization of the electronic information resources. ${ }^{11}$

They also reveal that frequency of use of these resources indicated that a lot need to be done to increase e-resource use. A study conducted by Ogunmodede, Adio and Odunola (2011) revealed that out of the sampled population, 82 respondents were 300 level students, while 107 respondents which represented $44.0 \%$ were 400 level students, 54 of the sampled population belong to 500 level students of the institution. This implied 400 level students used the library than the other two levels. Similarly, Omehia, Obi and Okon (2008) conducted a research on student characteristics and use of library services in the University of Uyo. The findings revealed a significant difference between third and fourth year students and that $51 \%$ of the total variance in the use of library services was attributed to the influence of students' year of study. ${ }^{12}$

\section{Research Methodology}

The design adopted for this study was a survey research design. This research was conducted in five of the six states that constitute the South-South geo-political zone of Nigeria. The targeted population of the study was all the registered library users in universities in South-South Zone of Nigeria. There were about twenty universities in the area. From the targeted population, samples of 1000 registered users were used from five universities in the Zone. Roughly two hundred students were used from each of the university for the study. The instrument for data collection in this study was the questionnaire. The questionnaire had two sections, Section A and Section B. Section A contained items that source for information on demographic data of the respondents. Section B comprised of items that measure the variables that are continuous. The questionnaire was constructed after the Likert four point scales. Section A included; Name of institution, sex, faculty, year of study, age and department. Section B included items on a Likert scale with four point alternative responses ranging from strongly agree (SA), Agree (A), strongly disagree (SD) and Disagree (D). The data collected were analysed using the SPSS version 10.0(1999). The independent t-test and one-way analysis of variance (ANOVA) were used to test the hypotheses.

\section{Results}

Hypothesis 1

The null hypothesis states that gender does not significantly influence utilization of information resources amongst undergraduates. To test this hypothesis, the utilization of information resources among undergraduates was compared amongst male and female undergraduates using the independent t-test analysis. The result is presented in Table $1 .{ }^{13}$

Table 1: Independent t-test analysis of the influence of gender on undergraduate's utilization of information resources

\begin{tabular}{|l|c|c|c|c|c|}
\hline Gender & $\mathbf{n}$ & $\overline{\boldsymbol{X}}$ & SD & $\mathbf{t}$ & p-level \\
\hline Male & 550 & 24.54 & 6.61 & -1.01 & .315 \\
\hline Female & 450 & 24.98 & 7.06 & & \\
\hline Total & 1000 & 24.74 & 6.82 & & \\
\hline
\end{tabular}

Not significant at the 0.05 level of significance

The information in Table 1 show that gender does not significantly influence undergraduates utilization of information resources $(\mathrm{t}=-1.01 ; \mathrm{p}=0.315)$. Hence the null hypothesis that gender does not significantly influence utilization of information resources is upheld at the 0.05 level of significance.

\subsubsection{Hypothesis 2}


The null hypothesis states that students' age does not significantly influence utilization of information resources among undergraduates. To test this hypothesis, the utilization of information resources amongst undergraduates of ages less than 20years, between 20 and 25years, 26 and 30years and 31year and above were compared using the one way analysis of variance (ANOVA) as reported in Table $2 .{ }^{14}$

Table 2: Summary data and one-way analysis of variance of the influence of age on undergraduates utilization of information resources

\begin{tabular}{|l|c|c|c|c|c|}
\hline \multicolumn{1}{|c|}{ Age } & N & $\overline{\boldsymbol{X}}$ & SD & & \\
\hline Less than 20years & 282 & 25.05 & 6.29 & & \\
\hline 20-25years & 507 & 24.98 & 7.16 & & \\
\hline 26-30years & 182 & 23.71 & 6.83 & & \\
\hline 31years and above & 29 & 23.90 & 4.81 & & \\
\hline Total & 1000 & 24.74 & 6.82 & & \\
\hline Source of variance & SS & Df & Ms & F-ratio & p-level \\
\hline Between groups & 268.283 & 3 & 89.428 & 1.929 & .123 \\
\hline Within groups & 46167.073 & 996 & 46.352 & & \\
\hline Total & 46435.356 & 999 & & & \\
\hline
\end{tabular}

Not significant at the 0.05 level of significance

The information in Table 2 shows that age does not have any significance influence on undergraduates utilization of information resources $(\mathrm{F}=1.929 ; \mathrm{p}=0923)$. Hence, the null hypothesis that students' age does not significantly influence utilization of information resources among undergraduates is upheld at the 0.05 level of significance. ${ }^{15}$

Hypothesis 3

The null hypothesis states that there is no significant influence of academic level on utilization of information resources among undergraduates. To test this hypothesis, the utilization of information resources was compared across undergraduates at different levels of academic program using the one-way analysis of variance as reported in Table 3.

Table 3: Summary data and one-way analysis of variance of the influence of academic level on utilization of information resources.

\begin{tabular}{|l|c|c|c|c|c|}
\hline Academic level & $\mathbf{N}$ & $\overline{\boldsymbol{X}}$ & SD & & \\
\hline 100 level & 160 & 25.31 & 5.88 & & \\
\hline 200 level & 271 & 25.18 & 7.35 & & \\
\hline 300 level & 253 & 25.26 & 7.09 & & \\
\hline 400 level & 224 & 22.87 & 6.34 & & \\
\hline 500 level & 92 & 25.54 & 6.39 & & \\
\hline Total & 1000 & 24.74 & 6.82 & & \\
\hline Source of variance & SS & Df & Ms & F-ratio & p-level \\
\hline Between groups & 1015.987 & 4 & 253.997 & $5.564^{*}$ & .000 \\
\hline Within groups & 45419.369 & 995 & 45.648 & & \\
\hline Total & 46435.356 & 999 & & & \\
\hline
\end{tabular}

*Significant at the 0.05 level of significance

The information in Table 3 shows that there is a significant influence of academic level of students and their utilization of information resources $(\mathrm{F}=5.564 ; \mathrm{p}=0.00)$. Hence the null hypothesis that there is no significant influence of academic level on utilization of information resources among undergraduates is rejected at the 0.05 level on utilization. To find out how the academic level influences the utilization of information resources, a Post Hoc test using the Fisher's Least Significance Difference (LSD) test was performed as reported in Table $4 .{ }^{16}$

Table 4: Fisher's Least Significance Difference test of the influence of academic level on utilization of information resources among undergraduates

\begin{tabular}{|l|c|c|c|c|}
\hline \multicolumn{2}{|l|}{ Academic level } & Mean difference (I-J) & Standard error & p-level \\
\hline 100 level & 200 level & .13169 & .67360 & .845 \\
\hline & 300 level & .05163 & .68244 & .940 \\
\hline & 400 level & $2.44196^{*}$ & .69934 & .001 \\
\hline & 500 level & -.23098 & .88401 & .794 \\
\hline 200 level & 300 level & -.08006 & .59065 & .892 \\
\hline
\end{tabular}




\begin{tabular}{|l|c|c|c|c|}
\hline & 400 level & $2.31028^{*}$ & .61010 & .000 \\
\hline & 500 level & -.36267 & .81524 & .657 \\
\hline 300 level & 400 level & $2.39033^{*}$ & .61985 & .000 \\
\hline & 500 level & -.28261 & .82255 & .731 \\
\hline 400 level & 500 level & $-2.67294^{*}$ & .83663 & .001 \\
\hline
\end{tabular}

*Significant at the 0.05 level of significance

The information in Table 4 shows that 200 level, 300 level and 500 level students do not significantly differ from 100 level in their utilization of information resources, but 100 level students have a significantly higher utilization of information resources than 400 level students. Also, 300 level and 500 level do not significantly lower utilization of information resources than 200 level students. The 300 level students have a significantly high utilization of information resources than 400 level students. Again, 500 level students have a significantly lower utilization of information resources than the 400 level students. ${ }^{17}$

\section{Discussion}

The first finding of this study shows that gender does not significantly influence undergraduates utilization of information resources. This finding is in line with that of Diyaolu, Afolake and Ibrahim (2015). They reported that the advent of technology has influenced the way human activities are being conducted. Everyone, whether male or female wants to move with the time especially in information acquisition. Both male and female need information on a daily basis. Both gender aimed a first class degree and as such the quest for information is very competitive. Both gender are very effective in computer skills and as such, retrieval of electronic resources is quite easy for them.

There are other variables that do not depend on gender, for instance, Ama-Abasi and Denga (2014), discovered that students' tendency to cheat in examination does not depend on gender and that both male and female students cheated alike. However, this finding is in contrast to Okiki (2011), Ford et al (2001), Funmilayo (2013), Baro (2011) and others, who discovered that male students made use of library information materials more than their female counterparts. ${ }^{18}$

Most of them gave the reason that females were normally less confident than males in handing technology and that they lack relevant competences. This result that males use the internet more than females is because men use the web for information gathering and entertainment and female for communication. Men prefer playing games on line, visiting adult-only sites, gambling, accessing news groups and discussion forums, staying abreast of news development and seeking information for personal use, while females use the internet to talk to family and friends, Odell, Korgen, Schumacher and Deluchi(2000); Scealy, Philipsand Stevenson (2002). It is likely that female students do not like to be stressed up and so must be sure of what they want before going for it. Thus they will only use the internet when they felt library resources are accessible (Smith, 2015). More studies need to be conducted on the issue of gender on use of library resources, as there are varying reports especially on works done with large sample size like that of Bassi and Camber (2011) and Applegate (2008).

That age does not have any significance influence on undergraduate utilization of information resources. This means that undergraduate students make use of library information resources not minding their age gap. Information utilization is for all, whether young or old. This result is in line with Korobili, Tilikidou and Delistaurou (2016), posited that age does not significantly influence utilization of library resources. The undergraduates fall within the same age bracket and this group of persons are very conversant with ICT and as such will likely make use of electronic resources in the library. Hayelom (2014) confirmed in his findings that age of students does not significantly influence use of library information resources. Also being on an active age, it is likely that age has no significant influence on utilization of library information resources. ${ }^{19}$

In contrast, Lucky (2016), Abosede and Ibikunle (2011), Popoola (2008), Dulle (2014), Quadric (2013) and others observed that age of students significantly influence utilization of library resources. This could be because as age increases, the probability of library use will decrease and as older students may not have had as much exposure to computers resulting in increased computer anxiety. It may also be due to the fact that some of the researches were conducted on postgraduate students who might be more advanced in age. Also the sample sizes used in most of the studies were small as compared to this study or work. With this, age of undergraduate students does not significantly influence use of library resources especially electronic resources. The fact that post UTME is being done with computers, every student whether male or female strives to be computer literate.

It was also seen that here is a significant influence of academic level of students on their utilization of library information resources. This implies that the academic level of students influences utilization of library information resources.

In this study the 100- level students and 300- level students made use of the library resources more than the 400level students. This is indeed a marked contrast to the work of Ajiboye and Tella (2007), Whitemore (2001), and Haylom (2014) who all observed that utilization of library resources increases with increasing year of study. Also Ogunmodede, Adio and Odunola (2011) posited that 400- level students used the library more than 300 level and 500 level. In this study it was observed that first year (100-level) and third year (300-level) students have significantly higher utilization of information resources than fourth year students. 
This unexpected picturesque may be a pointer to the fallen standard of research project by students in Nigerian Universities in the region of study. ${ }^{18}$

Final Year/Project students these days appear not to engage in resourceful research through the library to get information on productive research for their projects. Some do not go to the field for survey but stay at home to fill questionnaires. Students engage in employing others to write project for them. These may explain why 400-level students who should make the most use of library resources are found in this study to utilize library resources less than the first and third year students. This may also explain why fifth year students have significantly lower utilization of information than fourth year. Mapolisa and Mafa (2012) reported that the challenges being experienced by undergraduate students in conducting research in Open and Distance learning Universities in Zimbabwe included inability to make use of Library resources. Hon Justice Anthony Ekundayo quoted by Ekwenze (2018) stated that without Library a final year student writing research would be sharing the fate of a blind man holding a driving license and that the fate of a Law student who does not use the Library particularly when writing project is even worse.

Moreso 200-, 300- and 500- levels students are not significantly different from the 100- level in the utilization of library resources. This again shows the general apathy in the utilization of information by students in Universities in the South-South region of Nigeria. Agboola and Bamigboye (2011) contrasted with this study that there is no significance influence of level of students on utilization of library information resources. They also discovered that preference where given to third year students alone in one of the universities under study due to lack of technological facilities like the computer. The findings of this study present a call for a more serious approach to researches and projects conducted by final year students in our Universities; whether they are up to standard with adequate literature. ${ }^{19}$

Supervisors should do more to ensure that their students do really engage in literature searches both in the library and other information sources and actually go out to the field for their studies as this phenomenon may also be witnessed in the Post Graduate Studies.

\section{Conclusion}

Based on the results of the findings of this work, it is concluded that undergraduates' academic level has a significant influence on utilization of library information resources. Gender and age of undergraduate students do not significantly influence utilization of library information resources. Very worrisome in the result is the low level of utilization of library resources by the year four /final year students in universities in the South-South Region of Nigeria. Students should have positive attitude on utilization of information resources for maximization of resource utilization for improved academic performance and competitive global academic pursuit.

\section{Recommendations}

As a result of the findings of this study, the following are recommended

1. The university should develop an effective information use training programme.

2. Seminar and workshops should be organized every quarter of the year by the Library.

\section{Conflict of Interest}

The authors declare that there are no conflicts of interest in this paper.

\section{Source of Funding}

None.

\section{References}

1. Abosede AT. Ibikunle OO. Determinants of library use among students of Agriculture: A case study of Lagos State Polytechnic. Libr Philos Pract. 2011;6(1):40-521.

2. Adeleke DS, Nwalo IK, (2017). Availability, use and constraints to use of electronic information resources by postgraduates students at the University of Ibadan. Int $J$ Knowledge Content Dev Technol. 2017;7(4):51-69.

3. Adepoju OE. (2016). Demographic factors affecting ICT utilization by undergraduate students in some selected universities in Nigeria. Int J Libr Inf Sci Stud. 2016;2(1):29-42.

4. Agboola IO, Bamigboye OB. Students' level of study and user of library resources in Nigerian Universities: A comparative study. Libr Philosophy Pract.2011

http://unilib.un.edu/Lpp/Accessed on May4,2017.

5. Ajiboye JO, Tella A. University undergraduate students information seeking behaviour. Implications for quality in higher education in Africa. Turkish online J Educ Technol. 2007;6(1):40-52.

6. Ama-Abasi RD. (2009). Home environment and students' tendency to cheat in examination, PGDE Thesis, University of Calabar, 88.

7. Applegate R. Gender differences in the use of a public library. Public Libr Q. 2008;27(1):19-31.

8. Baro EE. Gender differences in information Access pattern among academic users. Turkish Online J Educl Technol. 2011;6(1):40-52.

9. Bassi MD, Camble E. Gender differences in use of electronic resources in University libraries of Adamawa State, Nigeria. Libr Philosophy Practice (e-journal), 2011;549.

10. Diyaolu AM, Folake ORO, Oluwadamilare IR. Influence of demographic factors on the use of digital library by the postgraduate students in private universities: A case study of Babcock and Covenant University in Ogun State. J Inf Knowledge Manag.

2012;2(5),http://pdfs.semanticscholar.org/4269/96e2a87. Accessed: $20^{\text {th }}$ May, 2017.

11. Ekwenze SAM. Project work for Students: An Appraisal. Nnamdi Azikiwe Univ Int Law Jurisprudence. 2011;2:1-15.

12. Ford N, Miller D, Moss N. The role of individual difference in internet searching; An empirical study. J Am Soc Inf Sci Technol. 2001;52(12):10-49.

13. Funmilayo DC. Gender differences in the use of academic resources. The case of FUTA library. Int J Libr Inf Sci. 2013 http://www. Academic journals. Org / IJLIS. 5(8), 256-261. (Accessed on 12 March 2017).

14. Hayelom T. Determinantsof information resources and services use among students and instructors in selected federal ATVET colleges in Oromiya National Regional State, Ethiopia. M.Sc. Thesis. 2014 
15. Korobili S, Tilidou I, Delistavral A. Factors that influence the use of library resources by faculty members. Libr Rev. 2006;55(2):91.

16. Mapolisa T, Mafa O. Challenges being experienced by undergraduate students in conducting research in Open and distance learning. Int J Asian Soc Sci. 2012;2(10):1672-84.

17. Momodu, O. M. (2014). Gender differences in library literacy among medical students in College of Medicine, Ambrose Alli University Ekpoma. Int J Basic, Appl Innov Res, IJBIR. 2014;3(2):60-4.

18. Odell PM, Korgen KO, Schumacher P, Delucchi M. Internet use among female and male college students. Cyberpsychol Behav. 2000;3(5):855-62

19. Ogunmodede TA, Adio G, Odunola OA. Library use education as a correlate of use of library resources in a Nigerian University. Libr Philosophy Pract. 201118.

http://unilib.unL.ed/Lpp/ Accessedon May 4, 2017.

20. Okiki, O. C. \&Asiru, S. M. (2011). Use of electronic information resources by postgraduate students in Nigeria. Influencing factors. Libr Philosophy Pract. 4-6 online resources-students perspective.

21. Okiki OC. (2012) Electronic information resources awareness, attitude and use by academic staff members of University of Lagos, Nigeria. Libr Philosophy Pract (e-J). p834.(online). Available at: http:// digital commons. unl. edu/. (Accessedon May 12, 2017).

22. Popoola SA. (2008). The use of information sources and services and its effect on the research output of social scientists in Nigerian Universities. Libr Philos Pract. 143. http://digitalcommons.unl.edu/cgi/view content .pdf. (accessed on 01 March, 2017).
23. Quadric GO. (2013) Influence of demographic factors on use of online library resources by undergraduate students in two private Nigerian University libraries. Libr Philosophy Pract. Paper 976. http://digital commons. un/ edu / libphi / prac / 976.(Accessed $5^{\text {th }}$ January,2017).

24. Scealy M, Philips JG, Stevenson R. Shyness and anxiety as predictors of patterns of internet usage. Cyberpsychol Behav. 2002;5(6):501-15.

25. Smith D. (2015) Does gender matter? University library access and career preparedness. Online Learning- 2015;19(4):1-12.

26. Whitmire E. Academic library performance measures and undergraduates library use and educational outcomes. School of library and information studies, University of WisconsinMadison, USA. http://polaris.gseis.uda.edu.pdf.( accessed $5^{\text {th }}$ March,2017). 2002

27. Whitmore E. (2001). A longitudinal study of undergraduate academic library experiences. $J$ Academic Libr. 2001;27(5):279-385.

28. Whiwhu BE. (2012). Public library information resources, facilities and services: User satisfaction with the Edo State central library, Benin-city, Nigeria. Library philosophy and practice (http:digitalcommons.unl.edu/lgi/viewcontnt.pdf) Accessed on May 4,2017.

How to cite: Daniel AAR, Agba UM. Students demographic variables as determinants of utilisation of information resources among undergraduates of universities in South-South Nigeria. IP Indian J Libr Sci Inf Technol. 2021;6(1):33-9. 